\title{
Proteolytic Conversion of Insulin-like Growth Factor-I to des (1-3) Insulin-like Growth Factor-I: A Further Site of Reg- ulation of Insulin-like Growth Factor-I Action
}

\author{
Liam J Murphy, Hiroyuki Yamamoto and Yang Lu \\ Departments on Internal Medicine and Physiology, University of Manitoba, Winnipeg, Canada
}

\begin{abstract}
In this review we discuss our progress in investigating the pro tease which is responsible for generating des (1-3) insulin-like growth factor-I (IGF-I), a more potent form of IGF-I devoid of the first $3 \mathrm{~N}$-terminal amino acid residues. Characterization of the protease activity indicated that it was most likely to be a member of the serine protease family. Although some activity was detected at neutral $\mathrm{pH}$, the activity was optimal at $\mathrm{pH}$ 5.5. The enzyme was purified from rat liver utilizing ion-exchange, chromatofocusing, phenylsepharose chromatography followed by high performance liquid chematography (HPLC). A single band of - $31 \mathrm{kD}$ was observed on silver stained sodium dodecyl sulphate-polyachylamide gel electrophoresis (SDS-PAGE) gels. We developed a rapid assay to quantify this protease activity in serum and tissue extracts. The activity was detected in mouse, rat, human serum and rat tissue extracts. The level of protease activity in the tissue extracts demonstrated the following order: liver $>$ testes $>$ heart $>$ skeletal muscle $>$ lung $>$ thymus $>$ kidney $>$ brain $>$ spleen. Protease activity was significantly higher in sera from hypophysectomized rats than in intact rats and growth hormone (GH) replacement reduced enzyme activity. In addition, serum protease activity was significantly elevated in diabetic rats and correlated with serum glucose concentrations. These data demonstrate that the proteolytic conversion of IGF-I to a more active form is enhanced under conditions associated with low IGF-I, insulin and GH levels and suggest that this conversion may be an additional site of regulation of IGF-I action.
\end{abstract}

Key words: variant IGFs, protease, growth hormone, hypopituitarism, diabetes

\section{Introduction}

The majority of circulating inslin-like growth factor-I (IGF-I) and present in the plasma is bound to a family of high affinity

Correspondence: Dr. Liam J Murphy, Room 435 BMSB, University of Manitoba, 770 Bannatyne Ave., Winnipeg Manitoba R3E 0W3 Canada binding proteins, the insulin-like growth factor binding proteins (IGFBPs). Four of the six IGFBPs so far characterized are present in human and rodent serum (1). The IGFBPs are thought to function as modulators of IGF bioavailability and can inhibit IGF-I action in both in vivo and in vitro situations. The majority of IGF binding capacity in both 


\section{Murphy et al.}

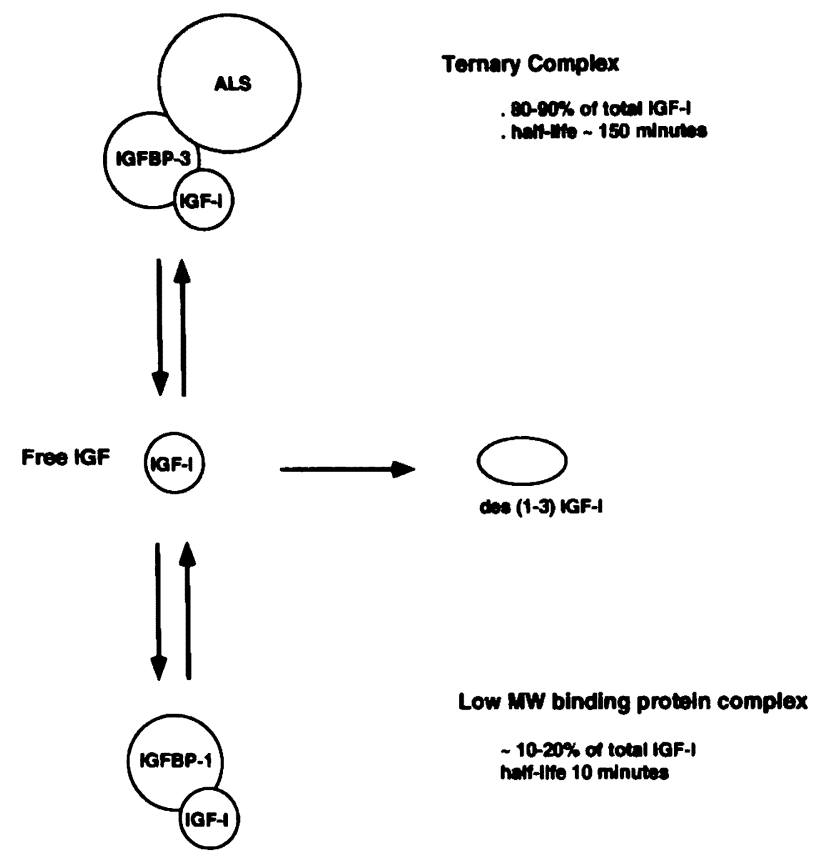

Fig. 1 A schematic representation of the interaction of the various compartments in which IGF-I is transported in the plasma.

human and rodent serum is attributable to IGFBP-3 which forms a relatively long-lived ternary complex with a non-IGF binding, GH dependent acid labile protein (2). IGF-I dissociates from this complex and reassociate with other binding proteins in addition to IGFBP-3 as shown in Fig. 1. A small fraction of the circulating IGF-I, probably less than $1 \%$ is free (3). Up to $40 \%$ of this free IGF-I may be des (13) IGF-I (4).

Factors which favour dissociation in vivo are not fully understood but both acidification and proteolysis of IGF binding proteins are likely to be important. Under in vitro acid conditions, IGF-I and/or IGF-I present in the ternary complex are liberated from IGFBP-3 and the ternary complex is irreversibly destroyed. Following neutralization IGF-I can rebind IGFBP-3 but the ternary complex does not reform because of the inability of the acidlabile subunit to bind to the IGF-IGFBP-3 complex (2). It is not known whether a similar sequence of events can result from the milder physiological acidification that occurs as blood acquires acidic metabolic products as it traverses the capillary bed. Free IGF-I and IGF-I bound to the smaller molecular weight binding proteins are more rapidly cleared from the circulation than is IGF bound to IGFBP-3 in the ternary complex (3).

Des (1-3) IGF-I is a naturally occurring IGF-I variant which was first isolated on the basis of enhanced potency. It is 10-50 times more potent than intact IGF-I in a variety of in vitro bioassays and is also more potent in vivo (5-7). This enhanced potency has been attributed to the reduced affinity of the IGFBPs for des (1-3) IGF-I. This variant has been identified in a variety of tissue extracts and biological fluids including brain $(8,9)$, uterus (10) and bovine colostrum $(11,12)$. Since des (1-3) IGF-I is present in avariety of tissue extracts and is biologically more potent than intact IGF-I we hypothesized that the generation of des (1-3) IGF-I may be a physiologically important step in modulating the activity and the clearance of IGF-I. We developed an assay based upon an immobilized biotinylated peptide to measure this activity and demonstrated that it was present in a variety of rat tissues (13). In this review we will discuss the progress that we have made in the isolation and characterization of the protease and our studies of the hormonal relation of this protease activity in serum. 


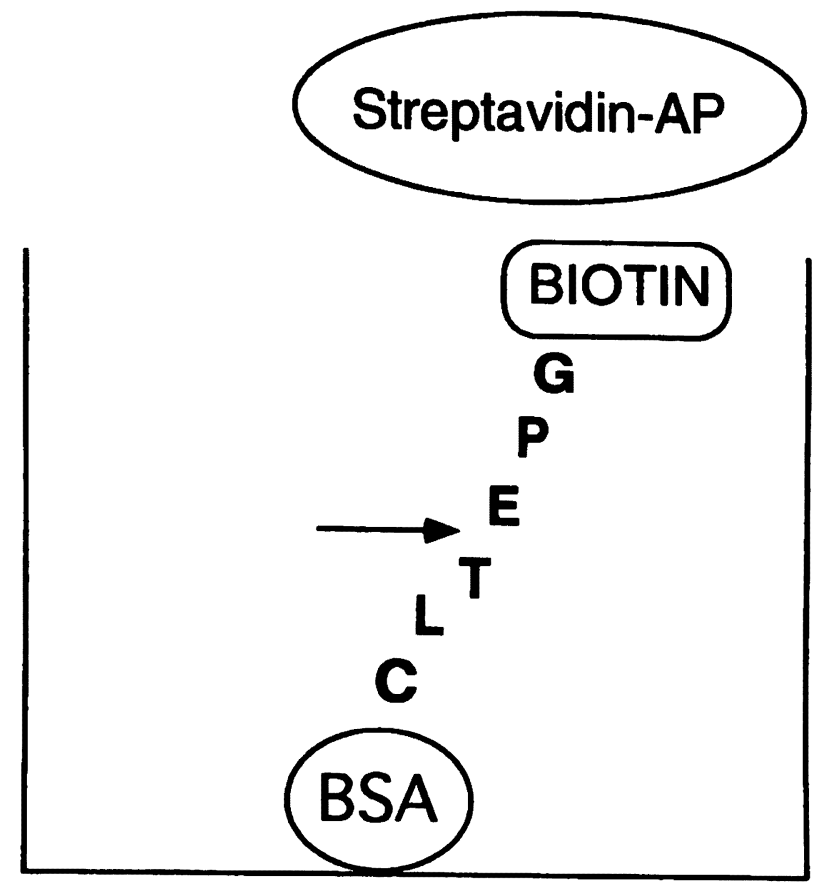

Fig. 2 A schematic representation of the assay protocol used to measure the protease activity which converts IGF-I into des (1-3) IGF-I.

\section{Characterization of the Protease Activity}

Protease activity was measure in serum and tissue extracts using a synthetic substrate with the sequence biotin-G-P-E-T-L-C coupled to bovine serum albumin (BSA) (4). The assay is depicted schematically in Fig. 2. The sequence of this peptide corresponds to the amino terminal end of IGF-I and includes the site of cleavage of intact IGF-I which results in the generation of des (1-3) IGF-I. However virtually identical results were obtained when a nine residue peptide corresponding to the $\mathrm{N}$ terminal sequence of IGF- I was used. The peptide-BSA conjugate was coated onto microtiter plates. Serum or tissue extracts were diluted with buffer and incubated in a final volume of $200 \mu \mathrm{L} /$ well. Enmiatic cleavage of the synthetic peptide resulted in loss of biotin label and the residual biotin label was quantified using a streptavidin alkaline phosphatase conjugate and $p$-nitrophenyl phosphate as a substrate. The absorbance was read in a plate reading spectrophotometer. Protease activity was calculated from the absorbance of the residual undigested conjugate using the formula: Activity=1-(OD of tested sample/OD of buffer control) and was expressed as a percentage.

Using this assay we determined that rat, mouse and human serum when incubated at $37^{\circ} \mathrm{C}$, resulted in a loss of biotinylated peptide from the microtiter plates. This was not due to non-specific proteolysis of the BSA, biotinases or biotin-binding proteins since the addition both BSA and biotin added to the buffer in varying amounts had no effect on the assay. Furthermore, $n$-bromosuccinimide and $p$-chloromercuribenzoate which inhibit serum biotin-binding protein activity had no effect of the protease activity in this assay system (4). With rat serum as a source of enzme activity we demonstrate a time and temperature dependent loss of enzyme activity. Similar levels of activity were detected in plasma and serum prepared from the same blood suggesting that activation of the clotting cascade or platelet aggregation and release were unlikely to be involved in generation of this activity.

While protease activity was easily detectable in freshly prepared serum from rodents or human subjects we noted that storage, particularly if there was repeated freeze-thaw cycles, resulted in a drrimatic loss of activity. No enzyme activity was detected in 


\section{Murphy et al.}

two batches of commercially available fetal calf serum. Furthermore, as little as $15 \mathrm{~min}$ utes exposure to $65{ }^{\circ} \mathrm{C}$ was sufficient to destroy enzyme activity. A variety of different buffer systems were used to determine the optimal conditions to detect enzyme activity in serum. Almost twice as much enzyme activity was detected at $\mathrm{pH} 5.5$ as at $\mathrm{pH} 7.5$ (4). In addition the protease activity was stable under acid conditions and was enriched 6 fold in acid ethanol extracts of rat serum. The presence or absence of divalent metal ions or chelating agents such as ethylene diamine terrcetic acid (EDTA) had no significant effects on the measured protease activity indicating that it was not a metalloprotease. A variety of commercially available proteases were tested in this assay system. Of the proteases tested only a few had any effect and the conditions required to demonstrate an effect indicated that it was unlikely that any of these proteases were responsible for the activity we detect in serum. For example collagenase only had activity at very high concentrations. Trypsin had some activity in this assay, however, its effect was more marked at neutral $\mathrm{pH}$ and could be reduced by increasing the amount of BSA in the buffer. Cathepsin $\mathrm{D}$ was active at $\mathrm{pH} 5.5$ but was not active at neutral $\mathrm{pH}$. Of a variety of protease inhibitors tested only soybean trypsin inhibitor, $\alpha 1$ antitrypsin and pepstatin A had a significant effect on enzyme activity (4). Furthermore, immobilized soybean trypsin inhibitor was able to remove protease activity from extracts of rat serum. These data suggest that the protease activity which we measured using this assay was a labile, trypsin-like, acid protease which was present in plasma as well as serum. We assumed that this pro tease
Table 1 Characteristics of the protease responsible for conversion of IGF-I to des (1-3) IGF-I.

\section{Acid stable, ubiquitous protease}

2. Present in plasma and serum

3. $\mathrm{pH}$ optimum of 5.5

2. Structurally related to trypsin and chymotrypsin 3. Molecular weight of $\sim 31 \mathrm{kDa}$

would, like trypsin, be a member of the serine protease family. The characteristic features of the protease are shown in Table 1.

To confirm that the protease detected using this assay, based upon a biotinylated synthetic peptide, was capable of converting IGF-I to des (1-3) IGF-I, a HPLC system was developed to separate IGF-I from des (1-3) IGF-I. Although the resolution of the IGF-I from des (1-3) IGF-I was poor, we were able to demonstrate that radiolabeled IGF-I was converted to des (1-3) IGF-I (4). In addition we demonstrated that when radiolabeled IGF-I was incubated with serum approximately $40 \%$ of the free IGF-I fraction as determined by Sephacryl S200 chromatography was $125 \mathrm{I}$-des (1-3) IGF-I whereas only a negligible $125 \mathrm{I}$-des (1-3) IGF-I peak was seen in the $50 \mathrm{kDa}$ fraction and no 125I-des (1-3) IGF-I was found in the $50 \mathrm{kDa}$ fraction.

\section{Tissue Distributlon of Protease Activity}

Aqueous extracts of various tissues were examined for protease activity. Activity was detected in all tissue extracts examined except adrenal gland extract. Fig. 3 shows the pro tease activity in the various tissues of normal adult male rats. When expressed in terms of organ wet weight, the liver proved to be the 


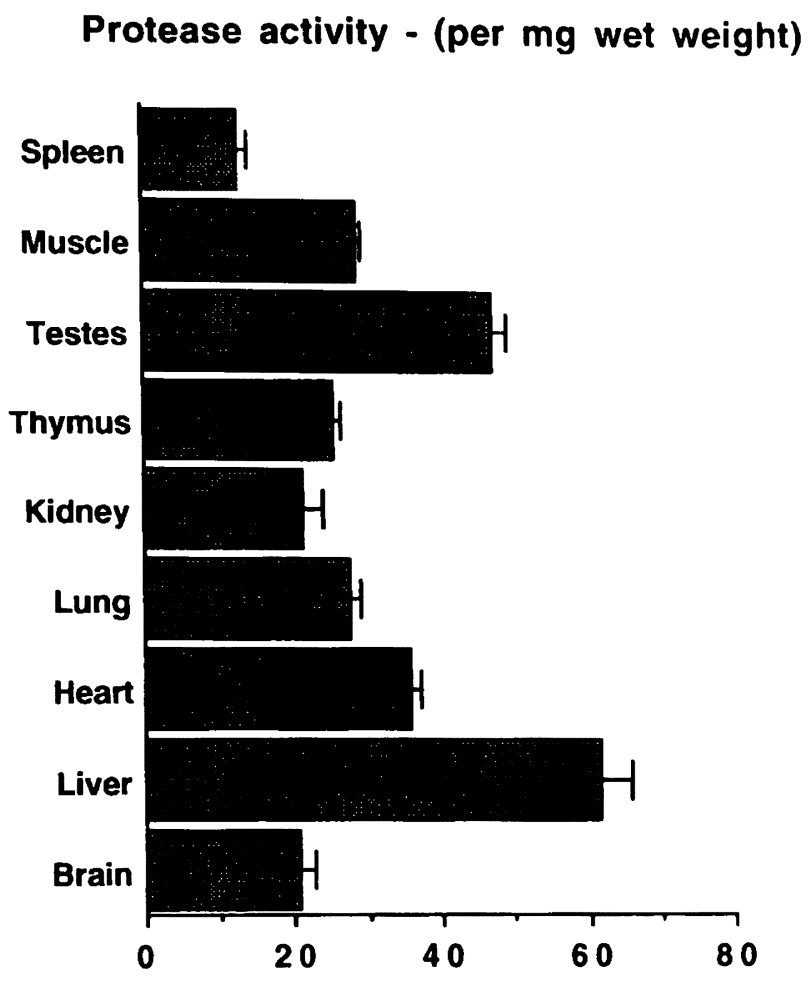

Fig. 3 Protease activity in various rat tissues as measured in the assay described in Fig. 2. Data represent the mean \pm SEM for 4-5 animals per tissue.

richest source of this activity. The order of protease activity in other tissues was: Liver> testes $>$ heart $>$ quadriceps muscle> lung $>$ thymus $>$ kidney $>$ brain $>$ spleen.

\section{Purification of Protease Activity from Liver}

The liver was selected as a rich source of protease for our attempts at purification. We characterized the time course of action, the temperature and $\mathrm{pH}$ dependency of the protease activity in hepatic extracts and found them to be identical to the serum activity. Thus, our working assumption was that the proteolytic activity detected in serum and hepatic extracts were due to the same enzyme. Using the biotinylated peptide substrate assay, we have developed a purification protocol to obtain highly enriched enzyme activity from rat liver. At each stage of the purification procedure the preparation was analyzed by polyacrylamide gel (SDS-PAGE) electrophoresis. The protocol involves an initial step of anion exchange chromatography of a high speed cytosol preparation. The fractions containing enzyme activity were then pooled and further analyzed. A variety of steps were tried and found to be of no value: these include heparin-sepharose, Con-A sepharose, lentillectin, and wheat germ lectin sepharose chromatography. Sephacryl S200 chromatography, phenylsepharose chromatography and affinity chromatography on a pepstatinagarose column resulted in some enrichment of enzyme activity. Using sephacryl S200 chromatography the activity was found to elute with an apparent $\mathrm{Mr}$ of 25-50 kDa. Soybean trypsin inhibitor and pepstatin-agarose affinity chromatography resulted in only marginal enrichrnent because of the difficulty in eluting the protease activity from these matrices. Phenylsepharose chromatography gave the most consistent results and the most significant enrichrnent of activity. However four predominant bands were apparent when the fractions contaning the enzyme activity were analyzed by SDS-PAGE and enhanced silver staining. The apparent $\mathrm{Mr}$ of these proteins were $42,31,25$ and $13 \mathrm{kDa}$. The material derived from the phenylsepharose column was subjected to a further purification step involving HPLC gel permeation chromatography on a SynChrom GPC 300 column. This last step indicates that the enzyme activity 


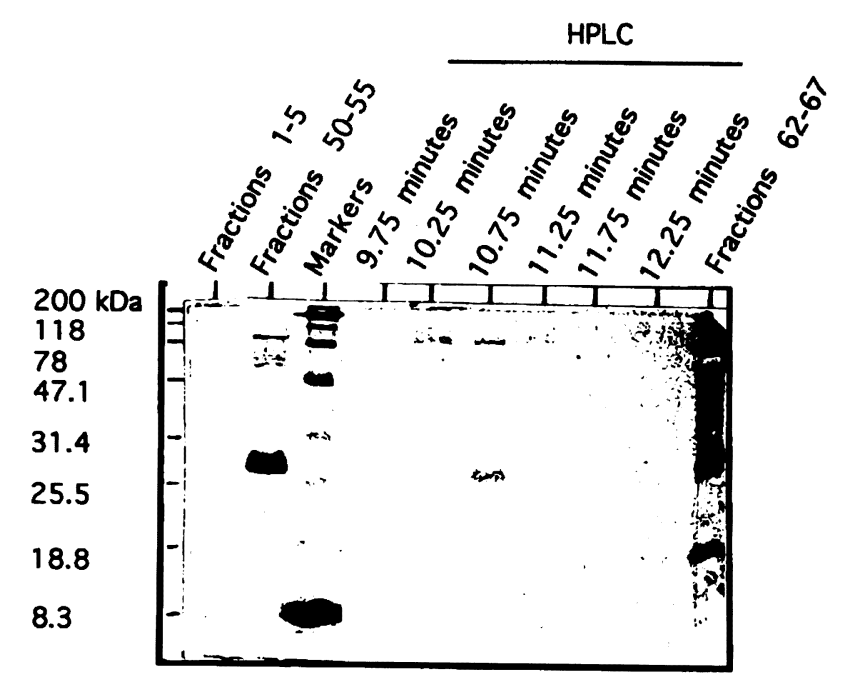

Fig. 4 Siver-stained SDS-polyacrylamide gel of the protease purified from rat liver. Fractions 1-5, 5055 and 62-67 were from the chromatofocusing column. Fractions 50-55 contained the majority of protease activity and was further purified by HPLC. Maximal activity was detected in the fraction correspoding to a retention time of 10.75 minutes.

was due to the $31 \mathrm{kDa}$ protein since the intensity of the band corresponded with the enzyme activity profile (Fig. 4).

\section{Effect of GH Status on Protease Activity in Various Rat Tissues and Sera}

To determine whether GH status had any effect on serum protease activity serum from saline-treated hypophysectomized (hypox) rats, GH-treated hypox rats and pituitary intact rats was compared (13). Serum protease activity was elevated in hypox rats. GH treatment of hypox rats significantly reduced this activity to levels that were not significantly different from normal pituitary intact rats. The enhanced protease activity in hypox rat serum was not a result of lower IGF-I concentrations and reduced competition with the biotinylated peptide substrate since when IGF-I was added directly to hypox rat serum to achieve concentrations comparable to normal rat serum, no significant reduction in pro tease activity was observed. One possible explanation for the enhanced protease activity in hypox rat serum is reduced levels of protease inhibitors. Serum levels and hepatic expression of Spi 2.1, a GH dependent serine protease inhibitor are reduced in hypox rats (14). Since Spi 2.1 is structurally related to $\alpha 1$ antitrypsin and $\alpha 1$ antichymotrysin $(15,16)$ both of which are able to partially inhibit the protease activity that we have identified in serum, it is possible that the enhanced protease activity that we detect in hypox rat serum is a result of reduced levels of Spi 2.1 rather than enhanced expression of the protease itself. Further studies are required to determine whether Spi 2.1 can actually inhibit the conversion of IGF-I to des (1-3) IGF-I.

\section{Protease Activity in Diabetic Rats}

Serum protease activity was also determined in streptozotocin treated diabetic rats. The serum protease activity was significantly increased in diabetic rats compared to control rats: $45.6 \pm 6.1 \%$ versus $38.7 \pm 5.6 \%, \mathrm{P}<0.02$ ). Insulin treatment of diabetic rats reduced the protease activity to that seen in control rats; $33.8 \pm 6.1 \%$ versus $45.6 \pm 6.1 \%, \mathrm{P}<0.001$ for insulin-treated diabetic rats compared to untreated diabetic rats. Furthermore, a positive correlation between protease activity and serum glucose level was observed. Since GH levels are also reduced in untreated diabetic rats it is not clear whether the observed increase in protease activity in these rats is a direct result of insulin deficiency or a conse- 


\section{Conversion of IGF-I to des (1-3) IGF-I}

quence of reduced GH levels.

\section{Future Directions}

The data that we have already accumulated provide a compelling argument that cleavage of IGF-I to des (1-3) IGF-I is an enzymatic process which can occur both in serum and tissues. Furthermore this process which converts IGF-I into a biologically more active form appears to be regulated by growth hormone and possibly also by insulin. A number of questions remain to be addressed. Firstly the nature of the protease and its relationship to other serine proteases can only be determined after the cognate cDNA has been cloned. When these molecular and immunological probes are available it will be possible to determine the exact mechanism underlying the GH regulation of this enzyme. The relationship between proteolytic conversion of IGF-I to des (1-3) IGF-I and the IGF binding proteins also warrants further investigation.

\section{Acknowledgments}

This work was supported by the Medical Research Council of Canada and by Canadian Diabetes Association. H.Y. was supported by a postdoctoral fellowship from the Manitoba Health Research Council. L.J.M is a recipient of an Medical Research Council Scientist award and an endowed Research Professorship in Metabolic Diseases.

\section{References}

1. Cohick WS, Clemmons DR. The insulinlike growth factors. Ann Rev Physiol 1993; 55: 131-53.
2. Baxter RC. Circulating binding proteins for the insulinlike gmwth factors. Tmnds Endocrinol \& Metab 1993; 4: 91-6.

3. Zapf J, Hauri C, Waldvogel M, Froesch ER. Acute metabolic effects and half-lives of intravenously administered insulinlike growth factor I and in normal and hypophysectomized rat. J Clin Invest 1986; 77: 1768-75.

4. Yamamoto H, Murphy LJ. Generation of des (1-3) insulin like growth factor-I in serum by an acid protease. Endocrinology 1994; 135 : 2432-40.

5. Bagley CJ, May BL, Szabo L, McNamara PJ, Ross M, Francis GL, et al. A key ftnictional role for the insulinlike growth factor-I N-termal pentapeptide. Biochem J 1989; 259: 665-71.

6. Ballard FJ, Francis GL, Ross M, Bagley CL, May B, Wallace JC, et al. Natural and synthetic forms of insulin-like growth factor-I (IGF-I) and the potent derivative, destripeptide IGF-I: biological activities and receptor binding. Biochem Biophys Res Commun 1987; 149: 398-404.

7. Gillespie C, Read LC, Bagley CJ, Ballard FJ. Enhanced potency of truncated insulin-like growth factor-I (des (1-3) IGFI) relative to IGF-I in lit/lit mice. J Endocrinol 1990; 127: 401-5.

8. Sara VR, Carlsson-Skwirut C, Andersson C, Hall E, Sjøgren B, Holmgren A, et al. Characterization of somatomedins from human fetal brain: identification of a variant form of insulim-like growth factorI. Proc Natl Acad Sci USA 1986; 83: 4904-07.

9. Carlsson-Skwirut C, Jørnvall H, Holmgren A, Anderson C, Bergman T, Lundquist 


\section{Murphy et al.}

$\mathrm{G}$, et al. Sara VR Isolation and characterization of variant IGF-I as well as IGF-2 from adult human brain. FEBS lett 1986; 201: 46-50.

10. Ogasawara M, Karey KP, Marquardt H, Sirbasku DA. Identification and purification of truncated insulin-like growth factor I from porcine uterus. Evidence for high biological potency. Biochemistry 1989; 28: 2710-21.

11. Francis GL, Read LC, Ballard FJ, Bagley CJ, Upton FM, Gravestock PM, et al. Wallace JC. Purification and partial sequence analysis of insulin-like growth factor-I from bovine colostrum. Biochem J 1986; 233: 207-13.

12. Francis GL, Upton FM, Ballard FJ, McNeil KA, Wallace JC. Insulin-like growth factors I and in bovine colostrum, sequences and biological activities compared with those of a potent truncated form. Biochem J 1988; 251: 95-103.

13. Yamamoto H, Murphy LJ.Enzymatic conversion of insulin-like growth factor-I (IGF-I) to des (1-3) IGF-I in rat serum and tissues: a further site of groth hormone regulation of IGF-I action. J Endocrinol 1995; 146: 141-8.

14. Yoon J-B, Berry SA, Seeling S, Towle HC. An inducible nuclear factor binds to a growth hormone-regulated gene. J Biol Chem 1990; 265: 19947-54.

15. Pages G, Rouayrenc JF, Le Cam G, Mariller M, Le Cam A. Molecular (tamcterization of three rat lievr serine-protease inhibitors affected by infiamation and hypophysectomy. Eur J Biochem 1990; 190: 385-91.

16. Hill RE, Hastie ND. Accelerated evolution in the reactive centre regions of serine protease inhibitors. Nature 1987; 326: 96-9. 